\title{
The Problematic of Education System in Indonesia and Reform Agenda
}

\author{
Agnes Sukasni ${ }^{1} \&$ Hady Efendy ${ }^{2, *}$ \\ ${ }^{1}$ Department of Human Resource Management, Jakarta State University, Jl. Rawamangun \\ Muka, RT.11/RW.14, Rawamangun, Jakarta Timur, 13220 \\ ${ }^{2}$ Scientist and Education Consultant, Tangerang, Indonesia \\ *Correspondence: Department of Human Resource Management, Jakarta State University, Jl. \\ Rawamangun Muka, RT.11/RW.14, Rawamangun, Jakarta Timur, 13220, Indonesia. E-mail: \\ agnessman31@gmail.com
}

Received: August 15, 2017 Accepted: September 19, 2017 Published: September 29, 2017

doi:10.5296/ije.v9i3.11705 URL: https://doi.org/10.5296/ije.v9i3.11705

\begin{abstract}
Education in Indonesia has not fully provide hope for the people through the values and benefits of education. This condition is evident from the low quality of graduates, lack of relevance of education in terms of the substance of the needs of society, and education actually used as the politicization of the district officials. Indonesia's ability to compete in global markets, the use of technology that can increase revenue and productivity, as well as the power to Visit Indonesia to investors, was formed through the existence of resources human. Indonesia must catch up in the standard of education with other countries. For that we need a re-identification of the problems of education in Indonesia and the solution to these problems and points of reform agenda.
\end{abstract}

Keywords: Curriculum, Education system, Education policy, Indonesia reform agenda, National education system 


\section{Introduction}

Education is one of the key vehicles for the intellectual and professional development of our people and plays an increasingly important role in supporting a stronger and more globally competitive Indonesia. However, education in Indonesia still has several problems related to quality and access as well as the even distribution of well-trained teachers. Limited access to education in rural areas has contributed to increased urbanization as families relocate to cities in order to acquire better education.

In Indonesia, efforts to the development of formal education was also carried out at various levels, from primary, secondary, to tertiary education. All these levels expected fulfilling functions and achieving national education goals, as contained in the Indonesia law on National Education System No. 20 of 2003 which serves to develop the ability and character development and civilization of the nation's dignity in the context of the intellectual life of the nation; and aims to develop students' potentials to become a man of faith and fear of God Almighty, noble, healthy, knowledgeable, skilled, creative, independent, and become citizens of a democratic and accountable.

Education sector is one of the sectors which contribute to the development of human capital. Based on the Human Development Index (HDI) which was released on 2016 Indonesia's HDI value for 2014 is 0.684 - which put the country in the medium human development category-positioning it at 110 out of 188 countries and territories. Between 1980 and 2014, Indonesia's HDI value increased from 0.474 to 0.684 , an increase of 44.3 percent or an average annual increase of about 1.08 percent (UNDP, 2015). HDI is a comparative measure of life expectancy, literacy, education, and standard of living for all countries around the world. IPM is used to classify whether a country is a developed country, developing or underdeveloped countries and also to measure the impact of economic policies on quality of life (UNDP, 2015). It is apparent how the condition of education in Indonesia today. In fact education is not fully provide enlightenment to the community through the values and benefits of education itself. The low quality of graduates is one proof that education in Indonesia has not been optimally developed. Relevance of education in terms of substance to the needs of the community is still considered low. Worse yet, education is the politicization of the district officials. Increasingly lagging education Indonesian nation with other nations, should make us more motivated to improve itself. The number of education issues that come to the surface is a picture of our educational practice. Questioning the problems facing the nation in terms of education, the authors are interested in creating a description of the issue and put forward solutions that would be contemplated through an article titled "Problematic Education System in Indonesia and Reform Agenda (Problems and Solutions)".

\section{Methodology}

Writing this paper using the methodology of the analysis system of education by doing research on data available in books and the other media then evaluate the national education goals set out in The Indonesia Constitution 1945 in comparison with what is stipulated in the 


\section{Al Macrothink

Law on National Education System and practice of education, The essence of evaluation that is who is going to be evaluated, what will be evaluated, and how the evaluation is done. The focus of this study is the evaluation of the education system on how the process of implementation of the goals of education, funding, teacher preparation, the preparation of the learning process and evaluation of education. Evaluation in this study using an evaluation model that is a model evaluation appraiser upward from the bottom in terms of evaluation of the citizens.

\section{Indonesia Education Problems}

Human Development Index (HDI) is a comparative measure of life expectancy, literacy, education, and standard of living for all countries around the world. HDI is used to classify whether a country is a developed country, developing or underdeveloped countries and also to measure the impact of economic policies on quality of life. Based on the latest release HDI Indonesia is in the category of Medium Human Development with 0.684 HDI Index, and ranked 110th out of 188 countries (UNDP, 2015). From this it is clear that education in Indonesia has not been optimal implementation in supporting the development of the nation. There are several aspects of education that we can look at and surfaced lately as important issues in education (Nuryata, Made, 2010; ASEAN State Education Report, 2013; Times Higher Education, 2013). Figure 1 below shows the contribution of each component index to Indonesia's HDI since 1980.

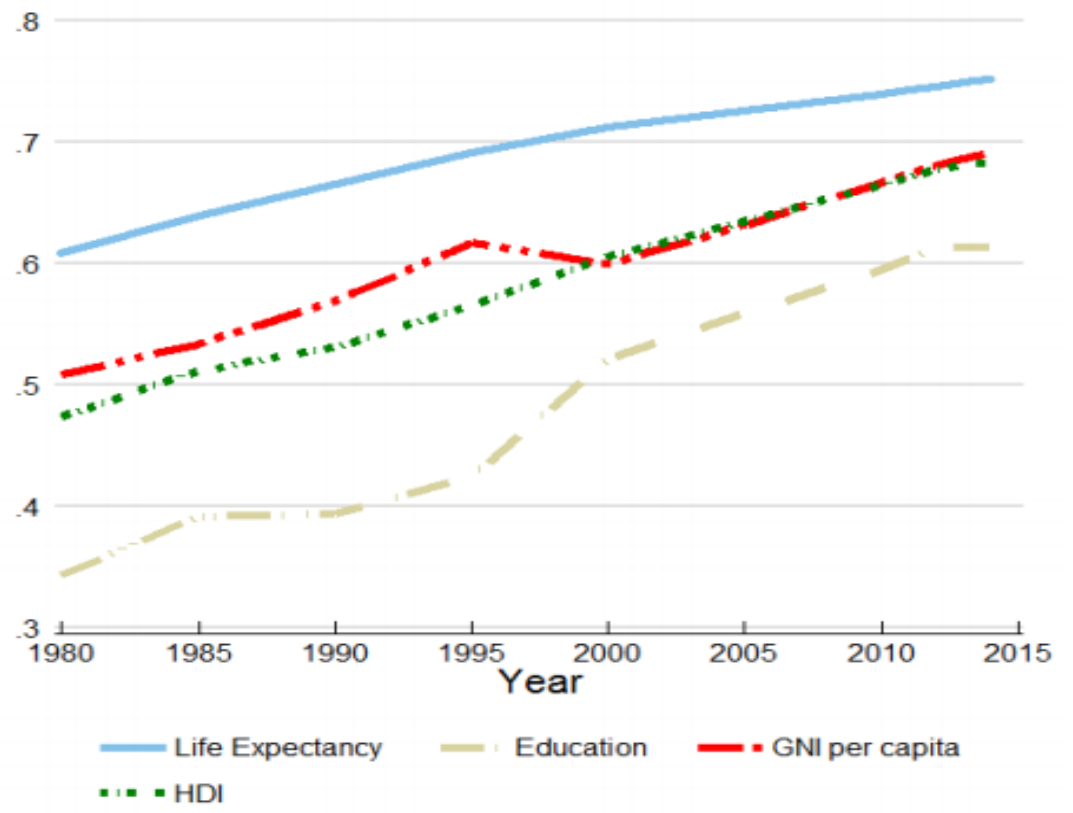

Figure 1. Trends in Indonesia's HDI component indices 1980-2014 Source: UNDP Report, 2015 
Table 1. Reviews Indonesia's progress in each of the HDI indicators. Between 1980 and 2014, Indonesia's life expectancy at birth increased by 9.3 years, mean years of schooling increased by 4.5 years and expected years of schooling increased by 4.3 years. Indonesia's GNI per capita increased by about 237.4 percent between 1980 and 2014 .

Table 1. Indonesia's HDI trends based on consistent time series data and new goalposts

\begin{tabular}{cccccc}
\hline & $\begin{array}{c}\text { Live expectancy } \\
\text { at birth }\end{array}$ & $\begin{array}{c}\text { Expected years of } \\
\text { schooling }\end{array}$ & $\begin{array}{c}\text { Mean years of } \\
\text { schooling }\end{array}$ & $\begin{array}{c}\text { GNI per capita } \\
(2011 \text { PPP\$) }\end{array}$ & $\begin{array}{c}\text { HDI } \\
\text { value }\end{array}$ \\
\hline 1980 & 59.6 & 8.7 & 3.1 & 2.901 & 0.474 \\
1985 & 61.6 & 9.9 & 3.5 & 3.431 & 0.512 \\
1990 & 63.3 & 10.2 & 3.3 & 4.337 & 0.531 \\
1995 & 65.0 & 10.2 & 4.2 & 5.930 & 0.566 \\
2000 & 66.3 & 10.7 & 6.7 & 5.308 & 0.606 \\
2005 & 67.2 & 11.2 & 7.4 & 6.547 & 0.635 \\
2010 & 68.1 & 12.5 & 7.4 & 8.267 & 0.665 \\
2011 & 68.3 & 12.7 & 7.5 & 8.642 & 0.671 \\
2012 & 68.5 & 13.0 & 7.6 & 9.060 & 0.678 \\
2013 & 68.7 & 13.0 & 7.6 & 9.446 & 0.681 \\
2014 & 68.9 & 13.0 & 7.6 & 9.788 & 0.684 \\
\hline
\end{tabular}

\subsection{Curriculum}

The curriculum is often regarded as a sacred document that should hold true that is contained in it being the only handbook for teachers. Many teachers are still afraid to be creative and innovative in teaching activities. Orientation curriculum is still seen from the completion of the subject matter. Teachers will be fearful when realizing that what is taught is not finished. Teachers have always pursued the curriculum targets, whereas the implementation of the learning experience a variety of different situations in each semester and annually. So that the learning process in the classroom is still largely limited to the completion of teaching materials without regard to students' understanding of the content of the material being taught. In fact, not all students can understand the content of the lessons and students who do not understand will be seen when answering a given test. In addition, the substance of the curriculum in terms of the density of the material is not significant to the allocation of available time. It is also one of the reasons that the material taught in class less meaningful and less noticeable relevance for students.

\subsection{Cost}

For most people the cost of education is still considered expensive. We see a clear example of the nine-year compulsory education program, which is actually still a chore for us. Due to the fact that many children of school age are not in school or drop out of school on the grounds of cost. Though there are grants from the center, but there nonetheless illegal levies are 
schools under the guise of an agreement between the school and parents. But immediately we cannot blame the school. Practice outside funding is not complete until the center at the school. Whether at the level where the funds are trimmed by rogue elements.

In addition, the practice of buying and selling the chair. It's sad to hear that. Only to find that children attend school or where desired by parents, parents are willing to spend money to be given to people who promise the chance to go to a school that is desired. And make no mistake, these people do not have to come from the school, many officials use his power to force the school to the student received. Is not this a form of corruption? If school students were accustomed to fraudulent practices such as this, do not blame a lot of corruptors in Indonesia.

\subsection{Purpose of Education}

The purpose of education is to the intellectual life of the nation. Should education is creating students who have a high power of reason, the ability analyzes of what is happening so that when experiencing a problem will be able to take the right decision. But the phenomenon, education, it can also be misleading. We can see the quality of our education is only measured by the diploma. Yet today many certificates are traded. And we cannot deny that many officials bought it. If we think, means that as long as the money we do not have to go to school, stay diploma we buy it. What is the condition of this nation, if everyone thought that way?

\subsection{National Exam}

Controversy regarding the implementation of the National Examination (UN) has been discussed since the school year 2002/2003 (Hidayat, Rais. 2013). In that year many people feel the deviations from the implementation of the UN, the first that were assessed in the UN only cognitive learners, but in education, the ability of learners includes three aspects, namely cognitive, affective, and psychomotor. Deviations second is that the determination of the standard of education is done unilaterally by the government. This is certainly depriving teachers in assessment. Third, the UN ignores elements of the assessment process. And, fourth irregularities, namely UN provides psychological and social burden to students. Students were forced to memorize lessons in the national examination.

Whereas the purpose of learning is to build understanding, instead of memorizing the lesson. Although in the last two years of un-procedural lessons above is minimized, but still, educators and students cannot breathe. Indeed, assessment by teachers during the educational process is in progress is taken into account, but the proportion is still small, only 0.4. While UN standards determined by the central government still has a proportion of 0.6 . It's also a psychological burden for students.

\subsection{Education Facilities}

Currently more we hear and see on the television news about the schools that are not feasible, where the students have to learn outside the classroom. Sad to see this, even to school in the capital also experienced something like this. Is not this country have of course the education 
budget can cope with such issues. Parliaments of every month doing a tour abroad under the guise of a comparative study, why only repair damaged schools requires a long time. Aggrieved course students as the next generation of this nation. How they are not alarmed if they have learned in the tumbledown buildings.

\section{Solutions to Problems of Education Indonesia}

Settlement of the problems of education should be comprehensive and integrated. For example, the government not only increase the education budget, but the resources and the quality of education remains low, then what to expect will not be achieved. If we look through the curriculum issues, things we need to fix is the implementation and demands given to implementing this curriculum. For example, teachers in schools are given the flexibility to run the curriculum (provided they are in the corridor) so do teachers are required to complete the teaching materials. Learning would be more meaningful if students really understand the teaching materials provided by the teacher, although with a bit of instructional materials, rather than be given a lot of instructional materials but is known only the surface of teaching materials.

For the cost, if all education officials to run the program correctly, then the education budget in this country will not be reduced. Their bad deeds of education officials, then all things are reduced and equitable distribution of education funding reception becomes unbalanced. Quality education is not cheap, or rather can say does not have to cost or free. The government should ensure that every citizen get a good education and government to provide assurance that the lower levels of society have access to quality education. Ideally education in Indonesia should be materialized by the minimum school-age children of high school, regardless of the child comes from a family of rich or poor.

After learning the hard way from the collapse of the country's economy during the 1997-1998 Asian financial crisis, which led to the end of former president Soeharto's long reign, Indonesia's political leaders quickly realized the importance of enhancing the quality of national education to ensure the country's future development. The collective commitment to begin a long-term investment in human capital finally materialized in 2002 during the fourth and latest amendment of the Indonesia Constitution, in which legislators agreed to include a paragraph in Article 31 on education, which stipulates that central and regional governments must allocate at least a fifth of their annual budget to the education sector.

However, it was not until 2009 that the government was able to meet the constitutional obligation following a Constitutional Court ruling in 2008, which declared that that year's state budget contravened the Constitution as it had yet to allocate 20 percent or more to educational spending. Consequently, the money pouring into the sector rose by 35 percent, from (IDR) 154.2 trillion (US\$12.9 billion) in 2008 to (IDR) 208.3 trillion in 2009. This year, the government allocated (IDR) 368.9 trillion for the sector and plans to spend another (IDR) 404 trillion in 2015 (Li Langing, 2013). Despite the government's soaring education expenditure during the past several years, recent data and studies have disturbingly shown that the massive investment has had very little impact on improving the overall quality of 
education. Although Indonesia has seen the compulsory years of schooling per student increase from 11.2 in 2005 to 12.9 in 2012, and the student-teacher ratio in primary education decline from 22 in 2000 to lower than 20 a decade later, the academic performance of Indonesian students is still far below that of students from other Asian countries, including China, Japan, South Korea, Singapore and Malaysia (UNDP, 2015).

Concerning the question of education based solely on diplomas and graduation National Exam. Diploma is important to demonstrate the legality of our ability, but should that need this diploma emphasizes the process of acquiring the diploma. There is no difference with the National Exam, the actual implementation of the National Examination is still relevant, but in the process there should be noted and corrected. For example, the passing standards are better adapted to the conditions and environment of each student.

When it comes to infrastructure will certainly die again the commitment of the government and education officials concerned. And not apart already discussed above, that everything must be returned to the private officials who have the authority, if they intend to be really useful for the country or simply looking to profit from the education conditions of this nation. If all the officers have a sense of honesty and a desire to develop the nation, is not easily affected by the environment, and can be firmly against the things that can harm our education system, quality education undoubtedly will be owned by the nation. Starting from the central authorities and to teachers who are in direct contact with students, should have the same commitment in advancing education in this country.

\section{Results and Discussion}

\subsection{Political Consistency}

Since independence, Indonesia has Article 31 of the Constitution requires the government to try and organize a national education system (paragraph 3). Countries should prioritize education budget of at least 20\% (paragraph 4). Governments should promote science and technology to uphold religious values and national unity for the progress of civilization welfare of mankind (paragraph 5). The provisions in the Constitution and then followed up with the Law on National Education System is the result of a political consensus. Based on the above statement can be drawn the conclusion that the failure of the implementation of the national education system is influenced by politics in both the determination of the values and character of man is needed, the determination of the amount of funds for education, the determination of the learning process, and the determination of the expected behavior of citizens. For inspiration only, China managed to create an amazing achievement, that is changing the socio-economic condition of the people, which is used only as a developing country, is only able to provide the basic needs of its people, then China turned and went into the early stages of becoming a prosperous society. Changes experienced China is a very significant change. All of China's success is inseparable from the efforts made by the Chinese leaders to implement reforms, particularly in education. Their belief build China through the education sector visible from ongoing expansion efforts undertaken since 1980 to early 1990. 
During this period, China's education continues to progress rapidly, and many innovations (BPS, 2016).

\subsection{Education Funding}

Inconsistency problem of education funding between 1945 mentioned in Article 31 paragraph (4) that the State must prioritize education budget of at least $20 \%$ of APBN / APBD with reality and practice of education funding. Fact that the budget provision of education by $20 \%$ APBN/APBD are in it already includes salaries of teachers and others. The inconsistent in education funding, education support causes such as school buildings, sports fields and other infrastructure tools become incompatible with the needs. Inconsistent funding has also led to the development of the school and the quality of graduates is low. Inability in carrying out the quality education led to Indonesia's position in global competition slumped. According to the UNDP 2006 Human Development Index (HDI) Indonesia only ranks 69th out of 104 countries. As of 2007, putting Indonesia ranks 108th out of 177 countries. Assessment conducted by the world population / UNDP put Indonesia in a position much lower than Malaysia, the Philippines, Vietnam, Cambodia, Laos even. While based on the Global Competitiveness Index in 2008 according to World Bank sources in 2009, Indonesia was ranked 54 of 134 countries. This position is still below the five ASEAN countries mentioned above. According to the 2006 Global Economic Forum on the Global Competitiveness Index (GCI), which in-release the WEF, the global competitiveness of Indonesia are in the collapsed position. For Asia, the Asian tiger Taiwan and Singapore ranks 5 and 6. While Japan, ranking 12th. China and India rank 49 and 50. In the same period, the quality of the Indonesian education system also was ranked 23. In the eyes of the WEF, Indonesia aligned with Gambia, in the category of low-income countries.

The Education Public Expenditure Review, released today, reports that despite Indonesia's move to allocate 20 percent of its total budget to education, the increase in spending over the years has yet to deliver the expected results. In its report, the World Bank revealed that the biggest payoff from Indonesia's greater education spending has been in terms of access, with impressive increases in enrolment rates over the last decade, especially for the poor. However, these improvements in access have occurred mainly in compulsory basic education, which includes primary school and junior secondary school. Access to senior secondary school and tertiary education, while improving on average, still remains extremely low for the poor. In addition, Indonesia's performance in international tests show that quality of education is still low and, most importantly, not improving. All the increases in access will only pay off if students graduate with basic skills.

The disappointing results can be partly linked to spending patterns: a large share of Indonesia's massive increase in resources has been used to pay for teacher salaries and teacher certification allowances. The increase in spending on teacher salaries was driven by a very fast increase in the total number of teachers, which continue to increase despite Indonesia already having one of the lowest student-teacher ratios in the world. While the teacher certification program has improved the livelihoods of teachers, it is yet to show the expected results in terms of student learning. Meanwhile, the share of the budget spent on 
early childhood education, senior secondary and higher education is still low by international standards. It is, thus, unlikely that these current patterns of spending will translate into improved quality of education and access to post-basic education for the poor.

Based on the above statement can be drawn the conclusion that there had been mistaken in education funding because, according to the Indonesia Constitution 1945 and the principles of the welfare state then the state must finance the entire delivery of education. The existence of clauses which asks people to take responsibility in education funding exactly as education funding policy in the era of the New Order. This is very unfortunate because the Law No.20 / 2003 was born during the reform. Funding education Indonesia as the lowest compare the other country in South East Asian. This means that the Indonesian government does not really care about the education to develop the nation. Based on the above explanation, the education funding from the state and local budgets should be adjusted to the 1945 Constitution that the state should fund the implementation of national education with all its consequences. These sources of funding can be pursued either through removal of subsidies on fuel oil and by imposing an education tax. So far, Indonesia is very afraid of the budget deficit but do not fear the education budget of deprivation. Extra funds for education does not automatically improve educational output as expected. Therefore, additional funds should be followed by reform education curriculum that emphasizes the mastery learning (mastery learning). But the complete learning will not be successful if it does not reform the teachers as the spearhead of educational success. To improve education financing, the Education Public Expenditure Review highlights the need to focus on increasing efficiency, equity and performance. The report recommends strategic reallocation of resources to higher levels of education and to scholarships for the poor programs; increased support from districts to schools; and improved budget planning, transparency and accountability.

\subsection{Provision of Professional Teacher}

The national education system as anything that can serve to achieve ideals such as in the preamble of the Indonesia Constitution 1945? The answer is the national education system of Meaningful learning process as a process of acculturation of various capabilities (multiple intelligent), value, and attitude. Of course the process of meaningful learning cannot be separated from the management and financing of the implementation of that support. One of the important things in the development process of meaningful learning is the availability of professional teachers.

Teacher certification policies, initially as an attempt to make the existing teachers become professional teachers. However, some indications show teacher certification policies failed to make teachers become professional. This happens because of teachers who pursue certification solely motivated pursuit of benefits of certification, once they get a certificate, there is no sign of them turn out to be professional teachers, both in designing, developing, implementing, assessing and diagnosing various problems faced by learners seen no difference between teachers who are certified by a yet certified. Therefore, with regard to the certification it is necessary to examine further the implementation of the certification policy so that in line with the purpose of creating meaningful learning process that leads to the 
achievement of the objectives of education according the preamble of the Indonesia Constitution 1945.

In an effort to improve education quality in Indonesia, in 2005 the government passed the Teacher Law, a comprehensive bill designed to raise the quality of teachers. A key reform required all teachers to acquire a four-year degree and be certified. Teachers who obtain certification then receive a professional allowance that effectively doubles their salary. By 2015, Indonesia's 2.7 million teachers expect to be certified. A new World Bank Group report, entitled "Teacher Reform in Indonesia: The Role of Politics and Evidence in Policy Making", assesses the impact of the Teacher Law and its reforms, on teacher knowledge, skills, and motivations. Equally importantly, the study looks at student learning outcomes. It also explores the bill's impact on the financing of education, and on the distribution of teachers throughout Indonesia.

The certification and conversion of employment status of all primary and junior secondary school teachers would imply that 89 percent of the total education budget in 2015 would need to be devoted to basic education. Given the [government's] commitments outside basic education, this level of spending is completely unsustainable,' they wrote. According to the 2005 Teachers and Lecturers Law, which was passed a year after President Susilo Bambang Yudhoyono started his first term in office, around 3 million elementary and secondary school teachers have to be certified by 2015 in the hope of improving their professional competence. The program, which requires teachers to have a bachelor's degree and pass both administrative and competency tests, is also aimed at improving teacher's welfare, as certified teachers are eligible to receive an additional allowance apart from their basic salary. Initially assumed that a salary increase would encourage teachers to perform better in schools. However, it turned out that most certified teachers have done almost nothing to improve their [teaching] skills or competency, making them no different than uncertified ones.

\subsection{Interest and Teaching Materials}

National education goals contained on education law, both in the law that never applies in Indonesia and which is still valid can be formulated that national education is expected to give birth to human religious and moral, to master knowledge and skills, physically and mentally healthy, and personality and be responsibility. The above objective is universal, so if contrasted with the characteristics of the modern era of globalization and all the challenges and opportunities that exist, then the national education are expected to bear the human quality Indonesian capable of supporting, among others: the political system stable democracy based on Pancasila, support economic system stable national physical infrastructure, technological infrastructure, human power infrastructure, developing entrepreneurial and growing small businesses, supports robust system of science and technology development, supports the advancement of culture in the arts, literature, as well as cognitive and normative dimensions of national culture, and support the consolidation of ethics social. Departing from the understanding of the characteristics of modern society in the era of globalization, it needs to be generated from the national education system is a human who has the skills, values and attitudes as follows: (1) people who have the skills, values and 
attitudes that allow it to participate actively and intelligently in the political process, (2) people who have the ability, work ethic, and discipline that enabled can be active and productive participation in various economic activities, (3) people who have the ability and scientific attitude to be able to develop science and technology through capability research and development, and (4) human beings who have a solid personality, character and moral and noble behavior. Based on the above opinion, the education in the era of globalization should be the main foundation and the cradle of kindness to transform individuals and communities innovate. Therefore, teachers and students have to do a collaboration as a partner for the sake of justice and the survival of life.

Selection of teaching materials in formal education / school is very strategic because of the teaching materials that learners will gain knowledge and skills to achieve the skills, values and attitudes appropriate national education goals. Selection of teaching materials are more selective so that the appropriate national education goals.

\subsection{Learning Process}

Education that took place during this generally do not produce the appropriate national education goals. This is partly due to the learning process is not meaningful because of the learning process so far never reached the level of joy of discovery on learning to know, joy of being successful in Achieving objective in learning to do and the joy of getting to gather to Achieve common goal in learning to live together. Failure of the education fun causes failure in forming personality (learning to be) steady, creative and independent. During this learning process more simply listen, take notes, and memorize.

Based on the explanation above, it is necessary to change the paradigm of learning paradigm just heard, recorded, and memorize the paradigm of the learning process student centre or cantered learning students by promoting learning process fun (joyful learning).

\subsection{Reform Agenda}

A number of the issues described above demonstrates the need for a reform agenda that is driven by a desire to improve the quality of basic education in Indonesia. This agenda should be based on the increase management capacity and accountability at each level of government, empowerment of schools in planning and implementing their own strategies to improve the quality of education, reduce the inequality of fiscal resources in the area of education, creating mechanisms of exchange and use information in a comprehensive system, build capabilities better teaching and back clarify the central institutional structures to fit a new mandate from the people. Now is the right time to implement these changes with immediate agenda: where the new government that under new leadership has gained huge mandate from the people of Indonesia.

\subsubsection{Invest in Capacity}

Implementation of new functions and roles of education, as stated in the Education Act 20/2003 requires more technical and managerial experience at every level of government. Capacity building can begin by defining performance standards and measures for the various 
functions of teaching at every level of government, to prepare a note on standards and basic competence, and auditing capabilities available today based on the size of the competencies required, where records are made simpler and easy to measure. The skills required to perform this function include expertise in financial planning and budgeting, personnel management, information gathering and communication. Increased membership can be done not only through formal training but also through real work to provide jobs directly in the work situation allows. To encourage better management at local government level, the central government can do a variety of ways below.

1. Announced earlier local budgets. Disclosure regarding grants and other assistance to be received by the regional administration before the start of the school year will give them enough time to plan a better budget and mobilize other resources if needed.

2. Provide special allocation funds to the local government level. The central government should provide more resources for education to local governments through a special allocation rather than through projects; of course, accompanied by oversight and accountability mechanisms are appropriate. The minister is currently supervises about 400 projects, which is the largest part of the budget allocation for education and still control the flow of capital and investment in improving the quality of education without interference from local governments altogether. The greater allocation of resources provided through the mechanism of Special Allocation Fund (Dana Alokasi Khusus / DAK), this will increase the capacity and capability building of local government management. DAK grants can finance minister of the part which is at the DIP funding. This is part of the implementation of the legislation once the new decentralized part of the overall government policy.

3. Reducing imbalances in funding. Local government expenditures currently account for about two-thirds of total spending on education. Overall actually sufficient funds available, which the central government spending coupled with the issuing of the regional administration reached almost 3 percent of GDP. However there are several districts that do not have sufficient resources to meet their educational needs, it results in the lack of education spending per pupil. The government must be able to determine the counties that really need these funds, then implement a funding program through DAK mechanism, to be able to provide services specific and localized.

\subsubsection{Apply School Based Management as the Basis of Reform}

The education law 20/2003 has given greater responsibility and authority directly to the school. School and community is expected to contribute in improving the quality of basic education significantly. Nevertheless there is a great diversity in the ability of schools in each region to implement the authority that has been given. The conditions of the Bali reflects the situation that occurred in other areas, then the school committee is still not fully use and exploit the mechanisms of authority given to them. Increasing school-based management can be done through: 
1. Prepare a lecturer who has a better ability to manage the school. Build and develop effective training programs in planning and budgeting, financial management, make an assessment and communication strategies for principals and school committee members. Creating an alternative program that will be given much needed given that the state of education in several regions in Indonesia.

2. Design and implement grants for schools comes from local government budgets. A number of grants to be able to cover basic operating costs as well as cover the costs of maintenance facilities were insufficient to meet minimum quality standards. These grants can be used for schools allocation mechanism based on a formula that is tied to use, easy to implement and there are a number of criteria that are easy to measure. To facilitate the management of an independent school, the form must help shape the flow of funds than other forms. Additional funds outside the operational funds can be obtained through a grant mechanism based on the proposals. This additional funding can be used to cover the cost of a number of special programs, such as the cost of developing the staff and more importantly the cost of investments in physical capital, such as the construction of a new classroom or laboratory, as well as for innovation and research.

3. Creating education grants aimed at the lower level community for projects that are based on the initiative of the school and the community. Some grants may stimulate the emergence of innovation and experimentation in the search for a good education system, particularly with a view to reducing inequality in poor areas. Special assistance is urgently needed for schools with a quality that is still below the minimum standard.

4. Manage the tuition. In the future, the district along with the community can mobilize more resources at their disposal in addition to grants from the central government. The Education Law 20/2003 is very clearly stated this. Even during the last three years, tuition has risen faster than the increase in prices in general. When tuition fees are important in improving the quality of education, will also be important to create a mechanism of transparency in the financial management and to ensure that the money the school is not to burden the poor. In poor areas of the school funding grants serve as a tool to reduce education spending coming from private money.

\subsubsection{Build Quality Assurance Surveillance Systems and National}

Information reporting system of education with the old centralized manner has ended. In the future, the system must be replaced with a mechanism that is more determined by the need for information and capacity, the system should also be able to serve the needs of management at every level of education. It must also be stressed proficiency standards and accountability. At the national level, information about education can provide an overview of the impact of the program and the allocation of resources. The information also helps to define the area or population that needs special attention, which in turn have an impact on improving the quality of policy making. At the local level, this information can be used as a tool for evaluation and monitoring. The information system also can be a diagnostic tool to get an overview of the challenges faced by the community and the school, as well as to identify the strengths and weaknesses of the teaching system is different. At the school level, 
educational information is a tool for evaluating the performance of pupils in certain subjects, and this information can also serve as a means of communication on the need and the success that has been achieved by the school to the parents and the school community at large. Improve incentives for quality assurance, monitoring, and dissemination of educational information. Cooperation in every level of government and schools can be facilitated through the use of financial incentives, as well as through professional pride of ownership joint information system, and also to provide an opportunity to learn from the districts that have been successful in building a good education system.

\subsubsection{Improving the Quality of Teaching Doing Career Teacher Level Reform}

Teachers are the main medium through which their students learn and allocation of funds for teachers' salaries take up most of the public budget. The use of these funds more accurately, not only have an impact on improving the quality of education, but also to meet the financing other important learning tools, such as for the provision of school books for students and professional development for teachers. The faculty in Indonesia agreed on the need the need to reform the teaching profession. However, these reforms must touch all stages of the careers of teachers, began training to teach pre-placement, and it also includes the promotion and career development.

1. Introducing transparent accreditation system. This accreditation system should include a training program before teaching for the next two years. The entire accreditation process be completed within the next 4 years. Various training programs are also required to obtain re-accreditation every five years. Then publish more widely the results of the accreditation process, including the results of the re-accreditation. To support this accreditation system, push the local government and schools to employ teachers who just came from programs that have been accredited.

2. Place and promote teachers based on quality. Stop purchasing practices and substitute teacher position by creating a practical exam and certification process for teachers at the national level, then pointed out openly registration process and selection. Publish the results of the teacher practice exam to the mass media. Teachers are also required to constantly update their certification periodically in order promotion.

3. Start the program for the entire career development for teachers and school leaders. The program must include preparation of pre-teaching, then teach and final placement of continuous professional development.

\subsubsection{Restructuring the Role of Department of Education}

As part of the change of government, the department of education required for the restructuring and transformation in the future. The main task of the ministry of education in a decentralized environment no longer provide direct educational services. Restructuring education department to reflect the new role in a decentralized environment. The task of the ministry of education should include policy making, set educational standards, measuring performance, empowerment of units of education have been decentralized to achieve quality standards, stimulate innovation and extend learning through experimentation, and pays great 
attention to the inequality of education between areas rich with the poor as well focus on the inability of poor areas to provide education with sufficient quality. Centralized institutions as well as a large bureaucracy is no longer needed to resolve the challenges faced by Indonesia at this time. In fact, it will hamper development.

\section{Conclusion}

The quality of education in Indonesia is still low. Though education has an important role in preparing human resources for the development of this nation. There are several aspects of education that recently surfaced in some discourse related to the problems of education in Indonesia, namely:

a. Curriculum implementation is not relevant to the demands society,

b. The cost of education,

c. Educational goals in the process deviate achievement,

d. Controversy implementation of national examinations, and

e. Many educational facilities are inadequate.

All of these are basically rest on honesty education educational workers in running the nation. If all educational workers have the honesty and the same commitment, namely to advance this nation, undoubtedly quality education will be obtained. All of these are basically rest on honesty educational workers in running the nation's education. If all educational workers have the honesty and the same commitment, namely to advance this nation, undoubtedly quality education will be obtained.

Education is the most powerful weapon which you can use to change the world (Nelson Mandela). The statement is in line with the thinking of the founding fathers of the Republic of Indonesia that incorporate education into Article 31 of the Indonesia Constitution (UUD 1945) of the founding fathers had a paradigm for thinking that the nation build, build schools. This shows that education played a strategic role in the development of the nation. It has been over 50 years of Indonesia establish a national education system. Great progress is perceived, but progress is felt still far from being written in the Indonesia Constitution of 1945. The existence of these facts indicate there is something wrong in the implementation of the national education system in Indonesia. Such errors can be seen from political support, whether it is political in the formulation of educational objectives, budget politics, and political organization of education such as preparing professional teachers, preparation means, inconsistencies between the goals of education and practice of education and between the goal with a model of educational evaluation.

In order to improve the quality of Indonesia, the necessary steps in a strategic and systematic planning, implementation, evaluation systems, and continuous improvement of the education system in Indonesia. Currently, Indonesia needs a 'grand design of the national education system "whose creation should involving all stakeholders in the Indonesian nation. And, in 
the later implementation requires a visionary leader and strong so that Indonesia can get up and running to catch a variety of pace from the other nations of the world.

\section{References}

ASEAN State Education Report (2013).

BPS. (2016). Centre Statistics of Indonesia.

Human Development Report. (2015). Work for human development. Briefing note for countries on the 2015 Human Development Report. UNDP.

Li Lanqing. (2013). Education for 1.3 Billion. Buku ini dikemas dalam 8 bab, 483, halaman, merupakan hasil wawancara Li Lanqing, Wakil Perdana Menteri Republik Rakyat Cina (RRC) periode 1993-2003 yang merupakan tokoh penting dalam reformasi pendidikan di Cina.

Nuryata, Made. (2010). Pembelajaran Masa Kini. Jakarta: Sekarmita

Rais Hidayat, Yuyun Elizabeth Patras. (2013). Evaluasi Sistem Pendidikan Nasional Indonesia. 2nd International Seminar on Quality and Affordable Education (ISQAE 2013), Indonesia.

Spending More or Spending Better. (2013): Improving Education Financing in Indonesia. World Bank Report. Jakarta. 14th March 2013.

Supardi U.S. (2012). Arah Pendidikan Di Indonesia Dalam Tataran Kebijakan Dan Implementasi. Jurnal Formatif, 2(2), 111-121.

Suyanto, (2002). Pendidikan untuk Masyarakat Indonesia Baru. Tantangan Global Pendidikan Nasional. Jakarta: Grasindo

Teacher Reform in Indonesia. (2014). The Role of Politics and Evidence in Policy Making. World Bank Report. Jakarta. 8th July 2014.

The Human Capital Report. (2016). Economic Forum. 2016.

Times Higher Education. (2013). Indonesia struggles to bridge its skills gap. November 14. 2013.

Undang-Undang (UU) Republik Indonesia Nomor 20 Tahun 2003. Tentang Sistem Pendidikan Nasional.

World Bank, op. cit.

World Bank. (2013). Spending more or spending better: Improving education financing in Indonesia. 


\section{Copyright Disclaimer}

Copyright for this article is retained by the author(s), with first publication rights granted to the journal.

This is an open-access article distributed under the terms and conditions of the Creative Commons Attribution license (http://creativecommons.org/licenses/by/3.0/). 